\title{
Musik Iringan Drama Tari Pengembaraan Panji Inukertapati Bermisi Perdamaian dan Toleransi
}

\author{
Budi Raharja ${ }^{1}$ \\ Fakultas Seni Pertunjukan, Institut Seni Indonesia Yogyakarta
}

\begin{abstract}
Accompaniment Music for The Journey of Panji Inukertapati Dance Drama for the Peace and Tolerance Mission. The writing article aimed to describing the accompany music for drama dance entitle Panji Inerktupati Journey in peace and tolerance mission. The performance described Inukertapati the journey and passed some regions in archipelago to looking for his lover, Dewi Sekartaji. The disccusion focus on dinamic performance structure, choosing sound and song reason, and its relationship to the movement. The result is the music consisted of Dijeridu instrument sound combined to electrical sounds and some Indonesian folksong (Javanese music, Malay, Papua, and Balinese music). The musics are arranged in single cone dinamic structure, are used to create performance musical atmosphere and as guidance dancers demonstrate movement; hovewer its relationship to movement are classified in three types: relationship of movement pattern with musical sound pattern; music phrase with movement phrase, and song character with movement character.
\end{abstract}

Keywords: Panji journey; drama dance; musical identity

\begin{abstract}
ABSTRAK
Tujuan penulisan ini untuk mendeskripsikan musik iringan drama tari berjudul "Pengembaraan Panji Inukertapati Bermisi Perdamaian dan Toleransi." Drama tari tersebut mengisahkan perjalanan Panji Inukertapati menjelajahi beberapa wilayah Nusantara mencari kekasihnya, Dewi Sekartaji. Pembahasan fokus terhadap dinamika pertunjukan, alasan pemilihan bunyi atau lagu, dan hubungan musik dengan gerak tari. Metode interview, observasi, studi literatur, dan studi dokumen digunakan untuk pengumpulan datanya. Hasil kesimpulan diketahui bahwa musik iringan drama tari tersebut terdiri atas bunyi Dijerido, bunyi aplikasi program DJ (monster dan drum), dan musik-musik daerah (musik Jawa, musik Melayu, musik Papua, dan musik Bali). Musik-musik tersebut dirangkai dalam struktur dramatik kerucut tunggal, digunakan untuk menciptakan atmofir musikal pertunjukan, dan sebagai pedoman penari memeragakan gerak-gerak tari. Hubungannya dengan gerak tari terbagi ke dalam tiga jenis, yaitu hubungan antara pola melodi dengan pola gerak, hubungan antar frase melodi dengan frase gerak, dan hubungan antar karakter melodi dengan karakter gerak.
\end{abstract}

Kata kunci: pengembaraan Panji; drama tari; musik identitas

\section{Pendahuluan}

Pendidikan atau penanaman kesadaran multikutural mempunyai peran penting dalam menciptakan perdamaian. Banyak cara dilakukan untuk itu, mulai dari memasukkan unsur-unsurnya ke dalam materi ajar, pemberian penyuluhan, dan bahkan pentas seni. Melalui jalur pendidikan, penanaman keasadaran multikurtural dilakukan melalui apresiasi seni dari berbagai daerah dan maupun memberikan pengalaman estetisnya. Apabial apresiasi dilakukan dengan pemberian pengatahuan, pengalaman estetis diberikan dengan melihat atau mendengar langsung musik dari berbagai daerah dan guru dapat mengajak siswa mengidentifikasi unsur-unsur musiknya, jenis alat musik yang digunakan, karakter lagu atau musiknya, tangga nada, hingga game yang

1 Alamat korespondensi: Fakultas Seni Pertunjukan, Institut Seni Indonesia Yogyakarta. Hp.: 089668912544.

E-mail: budiraharja51@gmail.com. 
digunakan dalam musik tersebut. Melalui kegiatan ini diharapkan kesadaran multikurltural mereka meningkat (Ambarwangi, 2013).

Pendidikan kesadaran mutlikultural dalam pendidikan multikultur juga dapat dilakukan dengan cara memasukkan unsur-unsur mutlikultural dalam matapelajaran, Model pendidikan ini mengintegrasikannya ke dalam mata pelajaran Pencicikan Kewarganegeraan, Seni Budaya dan Keterampilan, Seni Tari, Batik, Bahasa Indonesia, Karawitan, Tembang, dan Bahasa Jawa. Penanaman nilai-nilai multikultural dan seni budaya melalui kegiatan pengembangan diri dilakukan dengan cara penciptaan kultur sekolah yang kondusif dan kegiatan ekstrakurikuler yang meliputi dolanan anak, seni lukis, bahasa jawa, pencak silat, pramuka, drumband dan pianika (Wijayanti \& Indriyanti, 2017).

Pentas seni juga dapat digunakan untuk menumbuhkan kesadaran multikurltur. Di Pesantren Nabil Husein di Kalimantan Timur, pesantren yang guru (ustad) dan siswa (santri) nya berasal dari berbagai latar belakang budaya, memberi kesempatan kepada santri-santrinya pentas kreativitas seni; misalnya pentas seni modern, seni tradisional, seni Islam dan kesenian daerah (tarian Dayak, tari perang dan jape). Tujuannya adalah agar terjadi saling hormat menghormati budaya dan suku lainnya melalui pentas seni tersebut. (Abdul Ghafur, 2014 dalam Khojir, 2014: 76).

Peran seni, khususnya musik, dalam konteks tersebut adalah memberikan pemahaman kekayaan seni suatu daerah melalui ekspresi, apresiasi, kreasi, harmoni, dan keindahannya (Desyandri, 2014). Tujuannya adalah (1) membantu individu memahami diri sendiri secara mendalam menggunakan sudut pandang budaya lain, (2) memberi pengetahuan tentang etnis dan budaya lain. (3) mengurangi diskriminasi ras, warna kulit dan karakteristik budaya, dan (4) membantu para perserta didik menguasai kemampuan dasar membaca, menulis dan berhitug (Nurcahyono, 2018).

Mayarakat juga ada yang berperan dalam pendidikan mulikultural tersebut Pertunjukan yang dilaksanakan oleh Gerakan Masyarakat Miskin Kota Semarang berjudul "Panggung Rakyat", misalnya.
Pertunjukan tersebut menampilkan seni Rebana, Lagu-lagu Nasional, lagu Daerah, Seni lukis, dan lain-lain. Selain itu, kami (Sumaryono, Purwanto, dan Budi Raharja) juga merancang pertunjukan multikultural berjudul "Pengembaraan Panji Inukertapati Bermisi Perdamaian dan Toleransi". Pertunjukan ini berbentuk drama tari musikal yang mengisahkan pengembaraan panji mencari kekasihnya (Regina, 2014) sebagai pedoman memilih musik, gerak, kostum, dan properti. Artikel ini akan membahas hal tersebut dengan fokus pembahasan pada struktur dinamika pertunjukannya; khusunya bagaimana cara memilih bunyi atau lagu-lagunya, serta keterkaitan musik dengan geraknya.

\section{Teori Penyusunan Dramatika Pertunjukan}

Ada dua jenis struktur dramatika dalam pertunjukan, yaitu struktur kerucut tunggal dan dramatika kerucut ganda. Struktur dramatika kerucut tunggal adalah susunan tempo pertunjukan dari tempo pelan lambat laun semakin cepat dan di akhir pertunjukan bertempo tercepat; sedangkan dramatika pertunjukan kerucut ganda adalah struktur tempo yang terdiri atas beberapa kerucut tempo yang di bagian akhir masing-masing kerucut terjadi penurunan sedikit kemudian lambat laun semakin cepat dan di kerucut terakhir tempo tercepat (Hadi, 2017:76-78).

Struktur musik demikian bertujuan menghilangkan kejenuhan dari penggunaan tempo tunggal. Penyusunan demikian juga $\mathrm{u}$ menghidupkan dan membangun nuansa dari cerita tari tersebut (Subuh dan Prasetyo, 2009: 20). Bentuk musik iringan tersebut dapat berupa pertunjukan musik langsung atau dalam bentuk rekaman dan didukung background pertunjukan bangunan maupun film tentang suasana alam daerah-daerah tertentu (Ruastiti, Parmi, Nyoman, Suryani, \& Sudiana, 2018: 125).

\section{Teori Pemilihan Bunyi dan Lagu}

Menurut Supanggah ciri musik iringan tari adalah mendukung sajian tari, garapnya diarahkan untuk memenuhi garap sajian tari. 
Artinya antara gending dengan tari harus berada dalam satu bingkai yang sama (Rahayu, 2018: 92). Musik-musik untuk iringan tari atau iringan pertunjukan lainnya, mengandung simbol-simbol untuk menyampaikan pesan tertentu dan tokoh dijadikan acuan penyusunan iringan (Nalan, 2017). Dalam penelitian ini pemilihan musik dan gerak merupakan ekspresi kehidupan sekelompok orang yang digunakan untuk menyampaikan pesan perdamaian dan toleransi (Kleden-probonegoro, 2014). Oleh karena itu, pemahaman terhadap seni tersebut tidak lagi menggunakan analisis konteks kebudayaannya, akan tetapi dalam konteks penyampaian pesan kekayaan budaya Indonesia untuk perdamaian dan tolernasi. Bunyi/musik dan gerak tari dijadikan simbol-simbol verbal dan musikal (Santosa, 2011: 49) maupun simbol bentuk lainnya.

Bunyi dan lagu sebagai ekspresi kelompok, menurut bentuknya dikelompokkan dalam tiga kelompok; pertama musik yang meniru bunyi alam (bunyi kendaraan, binatang maupun bunyi lain yang ujudnya mirip dengan bunyi aslinya). Kedua meniru kemiripan bunyi alam (bunyi yang diasosiasikan dengan imej di alam, misalnya bunyi drum yang bertempo ajeg diasosiasikan dengan langkah orang berjalan), dan ketiga musik/bunyi sebagai simbol suatu daerah yang terbentuk berdasarkan kesepakatan dan jenis ini digunakan dalam artikel ini (Shepherd, John dan Wicke, 1997: 205-206).

Ada dua cara memahami pesan tersebut, menggunakan teknik analisis teks dan teknik analisis konteks. Teknik analisis teks adalah analisis musikal, yaitu analisis tentang repertoar lagu, pelarasan atau tangganada, garap atau aransemen dan pemain musik (Sukerta, 2011: 2). Analisis repertoar tersebut dalam penelitian ini digunakan untuk membahas pemilihan lagu; analisis tangganada membahas tangganada yang digunakan dalam lagu tersebut dikatikan dengan musik sebagai salah satu unsur ciri musik daerah, dan analisis aransemen membahas arasemen lagu atau melodi masing-masing yang dipilih sebagai penjelasan cirinya.

Analisis konteks adalah analisis musik dalam konteks budayanya. Analisis konteks dalam musik
(Sukerta, 2011: 2) dibedakan ke dalam analisis konteks karya dan analisis konteks kondisi masyarakat atau musik yang dikaitkan dengan situasi lokasi tempat musik tersebut berada, potensi kesenian, penyebaran, dan latar belakangnya. Teknik analisis konteks tersebut misalnya aplikasi musik dalam rutinitas budaya keseharian masyarakat Bali dijadikan kajian kontekstual pemahaman musik Bali (Malik, 2016: 89).

Teknik-teknik analisis tersebut juga digunakan untuk analisis gerak tarinya. Analisis teks dalam tari (Hadi, 2017: 23-89) terdiri atas analisis koreografis, bentuk gerak, teknik gerak, gaya gerak, jumlah penari, jenis kelamin dan postur tubuh, struktur ruang, struktur waktu, struktur dramatik, tata teknik pentas, analisis struktural, dan analisis simbolik. Analisis teks yang digunakan dalam makalah ini adalah analisis sruktural atau analisis tata hubungan antar bagian dalam bentuk tari; khususnya motif gerak (misalnya mendhak, gedrug, dan sejenisnya) sebagai ciri tari suatu daerah.

Analisis konteks dalam tari (Hadi, 2017: 97-98) adalah analisis pertunjukan tari yang dikaitkan dengan berbagai fenomena lain yang ada dalam masyarakat; misalnya agama, politik, pendidikan, ekonomi, pariwisata, dan sebaginya. Analisis konteks yang digunakan dalam artikel ini analisis adalah analisis gerak yang dikaitkan dengan lokasi atau tempat tari tersebut berada dan latar belakang kebudayaannya atau gerak sebagai ekspresi budaya daerah. Contoh dalam tari Balet banyak menggunakan gerakan lompat dan lari dengan sikap kaki bertumpu pada ujung kaki; gerak tari jawa timur banyak bertumpu tidak banyak gerak melompat dan banyak variasi gerak tangan; tari daerah pantai geraknya mengambang dan rasanya ringan (tari Japin), gerak tari rakyat bertumpu tanah dan rasanya berat dan kokoh (Hadi, 2017: 34-35).

\section{Teori Hubungan Musik dengan Gerak Tari}

Teori-teori tata hubungan musik dengan gerak tari dibedakan ke dalam hubungan normatif dan hubungan secara ilustratif. (Sumaryono, 2004: 55). Tata hubungan normatif adalah tata hubungan yang terjadi sebagai akibat adanya aturan atau norma- 
norma dalam musik yang harus diikuti gerak tari. Misalnya pola kendangan ngaplak dalam karawitan Jawa yang harus diikuti gerak tari srisig atau gerak tari berjalan cepat dengan langkah pendek-pendek. Tata hubungan ini sangat ketat, maksudnya tata hubugan yang terjadi antara satu pola tabuhan alat musik dengan satu pola gerak tari. Selain itu ada juga tata hubungan agak longgar. Apabila tata hubungan normatif terbentuk berdasarkan pola tabuhan dengan pola gerak tari; pada tata hubungan agak longgar terbentuk antara tabuhan alat musik tertentu dengan gerak tari; misalnya tabuhan kenong bersamaan dengan gerak tari seblak sampur.

Tata hubungan ilustratif adalah tata hubungan antara musik dengan gerak tari yang sangat longgar. Musik pada tata hubungan ini memberikan suasana gerak tari, misalnya gerak tari pelan diiringi dengan musik berkarakter tenang, gerak tari keras/cepat diiringi dengan musik bervolume keras dan cepat, dan sejenisnya. Tata hubungan ini dibangun secara sangat longgar, hubungan atas kesesuaian antara karakter musik dengan karakter gerak. Contoh adegan percintaan diiringi tembang macapat asmaradana; sedangkan gerak tari perang diiringi dengan gending sampak.

\section{Bentuk Pertunjukan}

Bentuk pertunjukan pengembaraan Panji Inukertapati bermisi perdamaian dan toleransi terbagi ke dalam lima adegan, yaitu (a) Introduksi atau Pembukaan, (b) Adegan Panji berangkat mengembara, (c) Adegan Panji Masuk Wilayah Melayu, (d) adegan Panji Masuk Wilayah Irian Jaya, (e) Adegan Panji Masuk Wilayah Bali, dan (f) Adegan Panji Kembali dari pengembaraan.

Lima tokoh ada dalam pertunjukan tersebut. Lima tokoh itu adalah Panji Inukertapati, Dewi
Sekar Taji, Klono Sewandono, Pengawal Panji Inukertapati, dan Rampak Buta. Personifikasi tokohtokoh tersebut menggunakan topeng (Gambar 1).

Pertunjukan tersebut menggunakan alur cerita sebagai berikut. Adegan introduksi Panji Inukertapati berusaha mempertahankan Dewi Sekar Taji dari penculikan Klono Sewandono dan usaha tersebut tidak berhasil sehingga Dewi Sekar Taji dibawa lari Klono Sewandono. Panji Inukertapati bersama pengawalnya mencari Dewi Sekar Taji dengan cara menjelajahi daerahdaerah Jawa, Melayu, Papua, Bali, dan kembali lagi ke Jawa. Penggambaran perjalanan tersebut menggunakan musik, tari, dan topeng; musik untuk membentuk suasana musikal, tari atau gerak untuk mengekspresikan nilai-nilai melalui gerak, sedangkan topeng sebagai personifikasi tokoh-tokohnya. Struktur dramatik atau dinamika musiknya menggunakan struktur dinamika kerucut tunggal. Pada bagian instroduksi musik bertempo lambat dan lambat laun semakin cepat, kemudian melambat dibagian menjelang akhir dan tercepat di bagian akhir.

\section{Musik Iringan Adegan Introduksi}

Musik yang digunakan untuk adegan ini adalah musik atau bunyi alat musik tradisional suku aborigin Didjeridu digabung dengan bunyi aplikasi DJ. Didjeridu adalah alat musik berbentuk silinder yang salah satu ujungnya lebih kecil atau mengurucut, berukuran panjang antara satu hingga dua meter. Alat musik ini milik masyarakat Aborigin, salah satu suku bangsa Australia bagian utara. Bunyi alat musik berfrekuensi rendah, antara 2,5 hingga 3,7 Hz. (Fletcher, 2007: 63-66). Bunyi tersebut memberi kesan serius, tegang, angker, dan sejenisnya digabung dengan bunyi monster dan bunyi drum aplikasi virtual DJ.

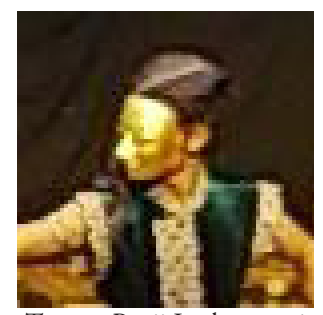

Topeng Panji Inukertapati

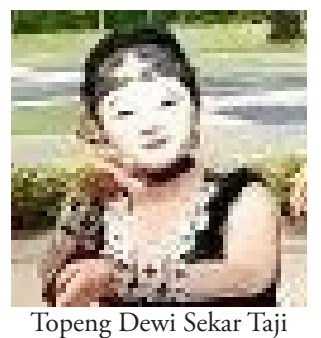

Gambar 1. Berbagai contoh topeng. (Foto: Raharja, 2018)

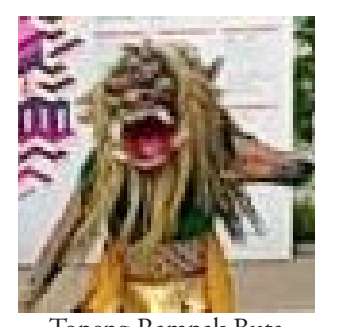

Topeng Rampak Buta

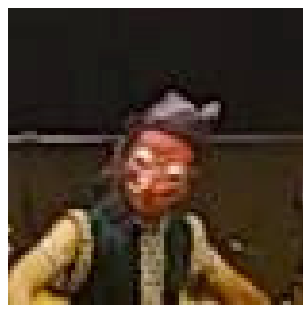

Topeng Klono Sewandono

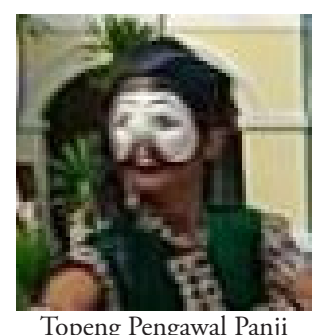

Topeng Pengawal Panji 
Musik ini digunakan untuk mengiringi adegan adu kekuatan antara Panji Inukertapati dengan Klono Sewandono (penculik). Adegan berakhir dengan ketidakmampuan Panji Inukertapati mempertahankan Dewi Sekar Taji sehingga Sekar Taji dibawa kabur oleh Klono Sewandono. Musik bernuansa tegang tersebut digunakan penari untuk memeragakan gerak perang. Mereka memeragakan gerak secara bebas, tanpa mempedulikan ritme musiknya. Musik dalam adegan ini digunakan sebagai latar atau ilustrasi gerakannya. Tata hubungan musik dengan tari yang demikian merupakan tata hubungan yang dibentuk berdasarkan kesamaan karakter gerak dengan karakter musiknya; musik berkarakter atau bernuansa tegang digunakan untuk memeragakan adegan tengang (Gambar 3).

\section{Musik Iringan Adegan Panji Berangkat Mengembara}

Musik yang digunakan untuk adegan keberangkatan pengembaraan Panji adalah gending Kinanthi Padang Bulan laras Slendro Patet Manyura Garap Bedhayan. Gending tersebut digunakan untuk mewakili wilayah (kebudayaan) Jawa yang meliputi (Hidayah, 2015: 140) Banyumas, Kedu, Yogyakarta, Surakarta, Madiun, Malang, dan Kediri; daerah-daerah yang kebisaan-kebiasaanya mengacu pada kebiasaan-kebiasaan di keraton Surakarta dan keraton Yogyakarta. Gending garap

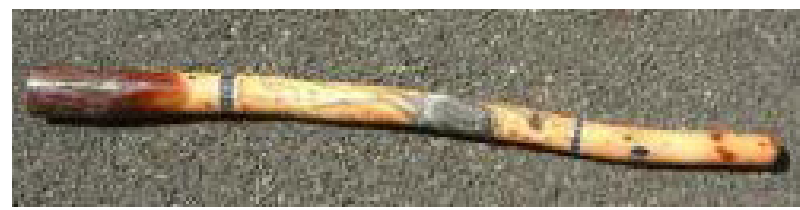

Gambar 2. Instrumen didjeridu.

(Sumber: http://www.wikiwand.com/id/Didgeridoo)

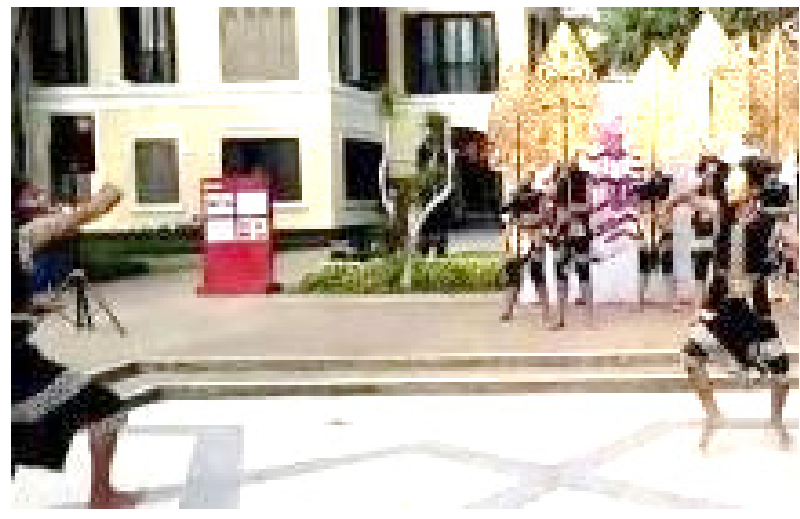

Gambar 3. Pose tubuh adegan Perang Panji Inukertapati dengan Klono Sewandono. (Foto: Raharja, 2018) bedhayan tersebut merupakan salah satu garap atau aransemen gending yang cara penyajian (tempo dan ritmenya) disesuaikan dengan kebutuhan pertunjukan tari Bedhaya atau tari menggambarkan sikap dan sifat-sifat ideal wanita Jawa (halus dan bernilai tinggi atau adiluhung). Gending tersebut menghadirkan suasana tenang, teduh, dan khidmat (Supriatna, Atang dan Sastra Negara, 2010: 21-22).

Tari tersebut dikelompokkan dalam tari sakral keraton Jawa (Surakarta dan Yogyakarta) yang menggambarkan bersatunya rakyat dengan raja (Herawati, 2010: 81). Untuk menghadirkan suasana sakral tersebut aransemennya pun juga bernuansa tenang, kidmat, dan agung. Untuk menghadirkan suasana tersebut digunakan kemanak, kenong, gong, dan vokal; dua kemanak ditabuh secara bergantian sebagai pedoman pemain kenong dan gong serta vokal menentukan tempo permainannya. Bunyi instrumen-instrumen tersebut, instrumen struktural itu (Supardi, 2013: 18), dibuat dalam bentuk rekaman, sedangkan vokalnya secara langsung atau dibawakan oleh penggerong secara langsung. Vokal ini dikelompokkan pada vokal bersama atau gerong yang dibawakan dalam bentuk bedayan (Suyoto \& Haryono, 2015: 70) (Notasi 1).

Gending garap bedhayan tersebut oleh penari digunakan sebagai tanda atau pedoman meragakan gerak-gerak tari yang merepresentasi karakter halus. Di bagian awal penari meragakan motif gerak tari

\section{Notasi Vokal}

Gending Kinathi Padang Bulan Laras Slendro Patet Manyura

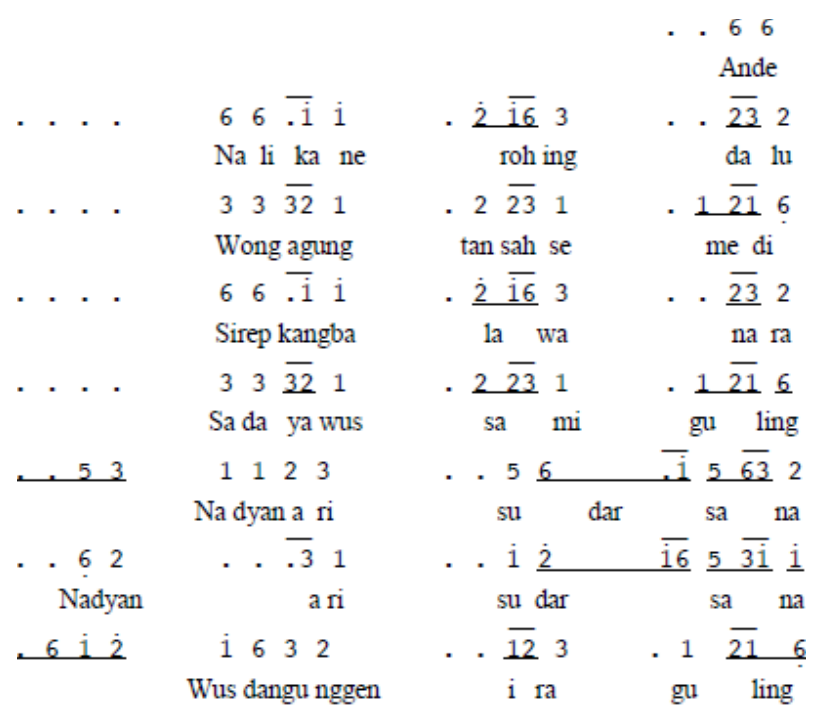

Notasi 1. Lagu Kinanthi Pandang Bulan. (Pengarang lagu: Anonim; Notasi: Budi Raharja) 
bedhaya dan kemudian meragakan motif gerak tari golek di bagian berikutnya (Gambar 4).

Tata hubungan musik dengan tari terjadi antara frase musik dengan frase gerak tari. Frase musik yang ditandai dengan tabuhan kenong atau gong digunakan penari sebagai tanda berakhirnya gerak tari yang panjang pendeknya ditentukan oleh jumlah hitungannya; misalnya frase gerak dengan hitungan empat adalah frase pendek sedangkan frase panjang adalah frase gerak yang jumlah hitungannya enam belas. Frase pendek gerak tari menggunakan pedoman frase musik yang ditandai dengan tabuhan kenong, sedangkan frase panjangnya dintadai dengan tabuhan gong.

\section{Musik Iringan Panji Memasuki Wilayah Melayu}

Musik yang digunakan dalam adegan ini adalah musik Zapin. Pemilihan lagu tersebut menggunakan pertimbangan sebagai berikut. Wilayah kebudayaan Melayu meliputi Negara Malaysia, Singapura, Philipina, Brunai Darusalam, dan Indonesia (Sumatra Barat dan Riau). Penduduk di wilayah tersebut mempunyai kebiasaankebiasaan yang dibentuk berdasarkan empat unsur, yaitu unsur Budaya Lokal, unsur Budaya India, Timur Tengah dan unsur Budaya Cina. Unsurunsur tersebut kemudian dikembangkan menjadi kebiasaan-kebiasaan yang berazaskan Islam (Bahar, 2017: 229-233).

Musik yang berkembang di wilayah ini adalah jenis Dendang dan Joged. Alat musik adalah rebana, biola, akordion dan gong; bertangga nada diatonik, syairnya berbahasa/logat Melayu dan berbentuk pantun. Alat musik-alat musik tersebut digabung menjadi sebuah ansambel, misalnya ansambel musik Melayu Ghazal mengunakan Harmonium,

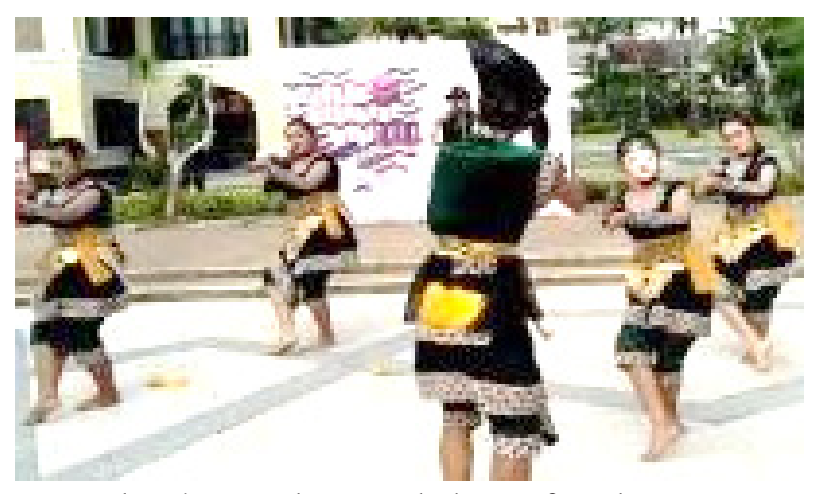

Gambar 4. Contoh pose tubuh motif gerak tari Jawa. (Foto: Raharja, 2018)
Tabla, Marakas, Gitar, dan Biola. Instrumeninstrumen tersebut mempunyai fungsi berbedabeda, misalnya memainkan melodi, harmoni, ritme dan nada (Asri, 2014: 103).

Musik tersebut (musik Melayu) salah satu fungsinya digunakan untuk mengiringi tari Melayu. Musik iringan tari ini dikelompokkan menjadi dua, yaitu musik internal atau musik yang dihasilkan dari anggota tubuh manusia (tepuk tangan, tepuk paha, tepuk kaki, tepuk siku, petik jari, dan hentakan kaki) dan musik eksternal atau musik yang dihasilkan dari alat-alat musik (saluang, bansi, talempong, dan gandang)(Rustiyanti, 2015: 153). Musik tersebut digunakan untuk mengiringi gerakgerka Tandak, Igal, Liul, dan Tari. Tandak adalah gerak yang menekankan hentakan kaki, Igal adalah gerak tari yang menekankan pada pengaturan kaki, Liul adalah gerak tari yang menekankan pada gerak tubuh dengan cara merendahkannya dan mengayunkan bersamaan dengan tangan, sedangkan Tari adalah gerak tari yang menekankan pada gerak lengan, tangan, dan jari (Rina Martiara, 2018: 57-58).

Pada perancangan ini musik Zapin (lagu Bunga Hutan) dipilih untuk membentuk nuansa musikal daerah Melayu. Zapin adalah salah satu jenis tari Melayu yang mendapat pengaruh kebudayaan Islam. Zapin yang artinya pergerakan kaki cepat tersebut digunakan sebagai media dakwah Islam melalui syair yang didendangkannya; misalnya sungguh murni bunga hutan, Suci bersih, bersih tidak bernoda, Kalau hati tidak iman jatuh kasih, kasih sampai tergoda. Syair lagu yang digunakan dalam pertunjukan ini bukan syair tersebut, akan tetapi syair lagu Harum Bunga Tanjung.

Musik tersebut menggunakan tiga alat utama yaitu gambus, marawas atau marawis, dan akordion. Gambus membawakan melodi, marawis pembawa ritme, sedangkan akordion sebagai penghias lagu (Notasi 2). Lagu tersebut digunakan oleh penari sebagai pedoman meragakan gerak-gerak tari Melayu (Gambar 5).

Peragaan gerak tari tersebut kadang-kadang mengikuti ritme musik dan kadang-kadang tidak. Tata hubungan demikian dikelompokkan ke dalam tata hubungan yang didasarkan atas kesesuaian antara ritme dan tempo musik dengan ritme dan tempo gerak tarinya. 
Musik Iringan Panji Memasuki Wilayah Papua

Musik atau lagu yang dipilih untuk membuat suasana musikal wilayah Papua adalah lagu Yamko Rambe Yamko. Wilayah kebudayaan Papua meliputi pantai Yapen teluk Cendrawasih, propinsi Papua. Masyarakat yang menempati daerah tersebut sebagian besar merupakan masyarakat rumpun Austronesia, Melayu Polenisia Timur. Mereka menempati wilayanh kecamatan Yapen Barat, Kabupaten Yapen Watopen, Propinsi Irian Jaya (Hidayah, 2015: 305). Bagi masyarakat yang mendiami wilayah pegunungan Papua Tengah secara garis besar dikelompokkan ke dalam masyarakat pesisir, kepulauan, dan masyarakat yang mendiami wilayah pegunungan (Somantri, 2010: 1 dan (Larasati, n.d.: 490).

Pada masa pemerintahan kolonial Hindia Belanda, wilayah ini dikenal dengan wilayah Nugini Belanda. Setelah berada bergabung dengan Negara Kesatuan Republik Indonesia, dikenal sebagai Provinsi Irian Barat (tahun 1969 hingga 1973) dan nama tersebut kemudian diganti menjadi Irian Jaya. Pada jaman dahulu masyarakatnya dikelompokkan

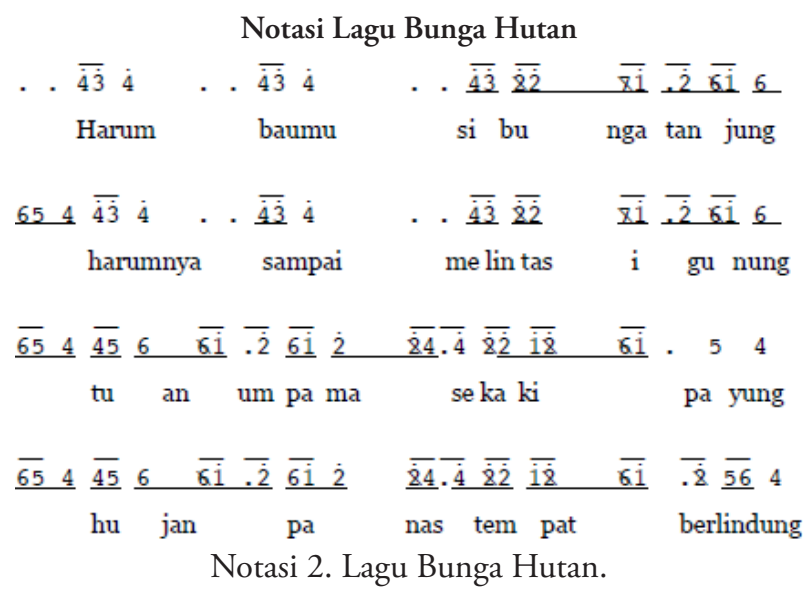

(Pengarang lagu: Anonim; Notasi: Budi Raharja)

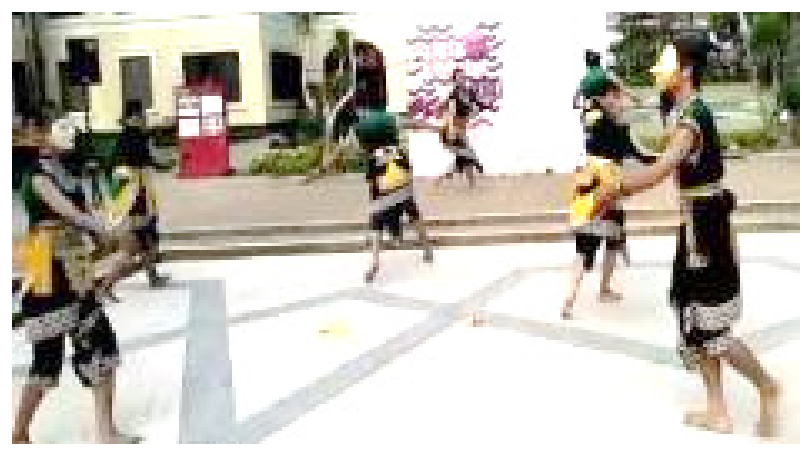

Gambar 5. Contoh pose tubuh motif gerak tari Melayu 1. (Foto: Raharja, 2018) ke dalam masyarakat pesisir atau mereka yang mengembangkan pola kehidupan mesolitikum dan masyarakat pedalaman dan pegunungan atau mereka yang mengembangkan pola kehidupan neolitikum (Hidayah, 2015: 303-305).

Kesenian Papua terdiri atas seni rupa (seni pahat, seni lukis, seni bangunan atau arsitektur, seni suara/musik, seni tari, seni sastra, dan seni drama. (Rumansara, 2014: 4). Lagu yang dipilih untuk adegan ini adalah lagu Yamko Rambe Yamko, Lagu bertemakan peperangan. Syair lagu ini menceritakan peperangan dengan slogan siapa yang ingin menjadi bunga bangsa adalah pahlawan yang rela berkorban, bahkan sampai mati, untuk mempertahankan negara Indonesia ini dari para penjajah (Notasi 3).

Pesan yang ingin disampaikan dalam lagu Yamko Rambe Yamko adalah pesan moral tentang perjuangan dan pengorbanan bagi bangsa. Keikhlasan akan pengorbanan tanpa pamrih terhadap bangsa merupakan jiwa kepahlawanan (bunga bangsa). Gerak tari ini menampilkan gerakan perang: gerak memanah, loncat, mengintip musuh, dan lain-lain (http://www.ragamseni. com/6-tarian-tradisional-papua-yang-sangatpopuler/). Gerak-gerak tersebut digunakan sebagai acuan penyusunan gerak yang menggambarkan nuansa budaya Papua; misalnya salah seorang penari memanggul penari lain kemudian berputar (Gambar 6).

Seperti halnya pada adegan sebelumnya, peragaan gerak tari tersebut kadang-kadang mengikuti ritme musik dan kadang-kadang tidak. Tata hubungan gerak tari yang mengikuti ritme

Yamko Rambe Yamko

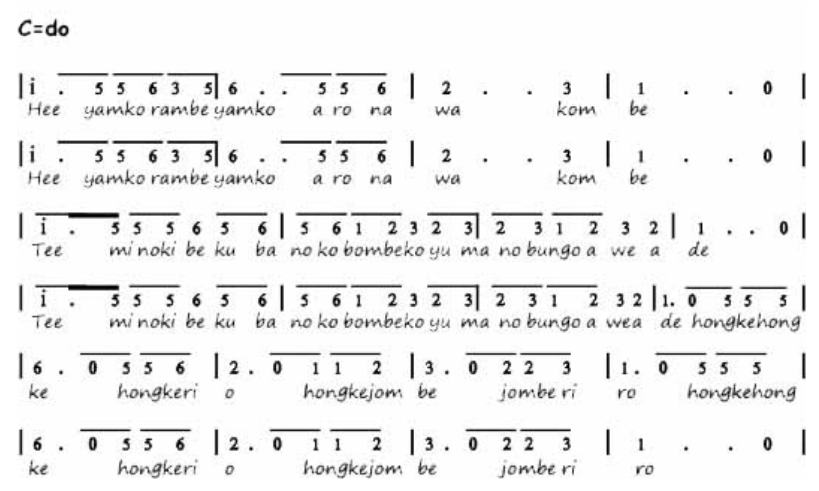

Notasi 3. Lagu Yamko Rambe Yamko. (Pengarang lagu: Anonim; Notasi: https://www.materibelajar.id/2017/12/ makna-lagu-yamko-rambe-yamko.html) 
musik tersebut tidak mengikuti aturan yang berlaku di wilayah tersebut, akan tetapi didasarkan atas kesesuaian antara ritme dan tempo musik dengan ritme dan tempo gerak tarinya.

\section{Musik Iringan Panji Memasuki Wilayah Bali}

Musik yang dipilih untuk menghadirkan suasana musikal dapat pertunjukan ini adalah gending Gilak. Masyarakat Bali yang mndiami wilayah pegunungan atau Kaja dan wilayah pesisir atau Kelot sangat setia menjalankan upacara agama Hindu (Hidayah, 2015: 51-53). Musik dan tari menjadi bagian penting dari upacara agama Hindu untuk memelihara keseimbangan antara kehidupan material dan spiritual, kehidupan nyata dan tidak nyata, maupun kehiduapan dalam hati dan luar hati. Tari jenis ini dikelompokkan ke dalam tari wali (sakral), bebali (pelengkap upacara) (Sugiartha, 2018: 3-12).

Musik Bali juga menjadi bagian penting dari upacara. Gamelan pada prosesi ritual Dewa Yadnya misalnya untuk menyenangkan hati para Dewal Ista Dewata (roh suci), mengundang kekuatan spiritual, menetralisir pengaruh negatif, dan mengurangi ketegangan atau emosi (Donder, 2005: 122). Musik tersebut dapat berbentuk vokal (gegendingan, macapat, kidung and kekawin) dan bentuk ansambel (bentuk terkecil terdiri atas empat instrumen dan yang paling besar teriri atas instrumen dan vokal yang mencapai jumlah 70).

Gending Gegilak digunakan untuk membentuk suasana musikal Bali pada adegan ini. Gegilak berasal dari gilak, artinya keras, digunakan untuk mengiringi tari baris yang berkarakter keras juga. Tari Baris adalah tari upacara yang sangat penting di Bali dan sifatnya sakral (suci), tari kepahlawanan berjiwa ksatria sejati, pantang mundur demi

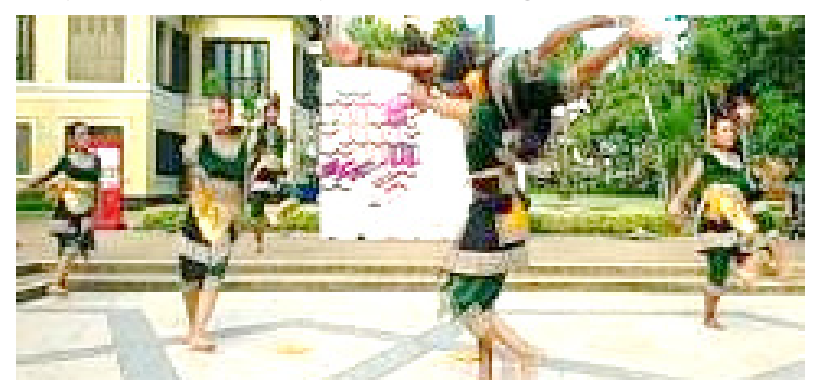

Gambar 6. Contoh pose tubuh motif gerak tari Papua 1. (Foto: Raharja, 2018) membela kebenaran (Iryanti, 2000: 84). Pada perancangan ini gegilak digunakan sebagai pedoman penari memeragakan gerak-gerak tari Bali dan penari Putri dalam menari menggunakan properti kipas sedangkan penari Pria memakai ikat kepala (Gambar 7).

Seperti halnya pada adegan sebelumnya, peragaan gerak tari tersebut kadang-kadang mengikuti ritme musik dan kadang-kadang tidak. Tata hubungan gerak tari yang mengikuti ritme musik tersebut tidak mengikuti aturan yang berlaku, akan tetapi didasarkan atas kesesuaian antara ritme dan tempo musik dengan ritme dan tempo gerak tarinya.

\section{Musik Iringan Adegan Panji Kembali ke Jawa}

Adegan kembalinya Panji Inukertapati diawali dengan para pengawal Panji bermainmain dan dilanjutkan Tari Rampak Buta. Pada bagian adegan pengawal Panji bermain diiringi gending Rampak Buta, gending bentuk lcanaran, akan tetapi temponya diperlambat menggunakan teknik tabuhan imbal saron barung. Garap atau aransemen demikian menjadikan susana atau tingkat ketegangan pertunjukan kendor atau menurun sedikit (Gambar 8).

Adegan jenaka tersebut seketika menjadi tegang ketika gending pengiringnya beralih ke tempo

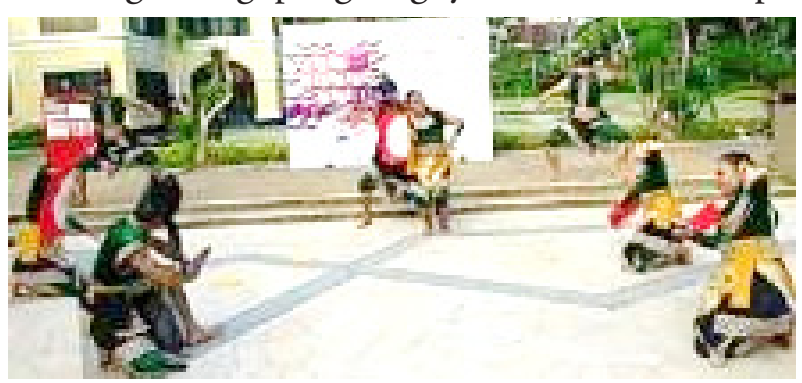

Gambar 7. Contoh pose tubuh motif gerak tari Bali 1 . (Foto: Raharja, 2018)

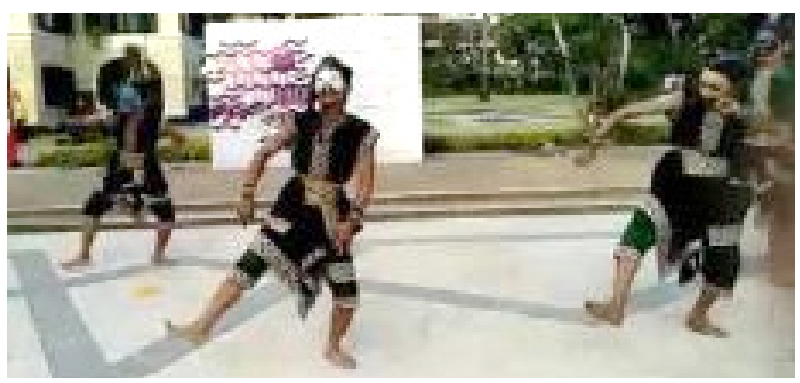

Gambar 8. Contoh adegan pengawal Panji bermain-main. (Foto: Raharja, 2018) 
cepat. Gending yang semula berirama tanggung dirubah menjadi irama lancar atau tempo cepat dan pada saat yang sama sekelompok penari Rampak Buta tampil di panggung. Pada saat ini penari memeragakan gerak tari yang menggambarkan kegagahan barisan raksasa. Gerak-gerak tersebut diperagakan sesuai dengan ritme-ritme gendingnya sehingga hubungan antara gending dengan gerak tari sangat kuat; tata hubungan yang dibentuk berdasarkan kesesuaian antara pola tabuhan alat musik dengan pola gerak tari.

Jenis Tari Rampak Buta yang digunakan dalam perancangan ini adalah Rampak Buta Grup Krincing Manis. Kelompok yang beralamat di Beran, Sleman tersebut merupakan kelompok mitra dalam perancangan pertunjukan ini. Ciri khas Rampak Buta grup tersebut adalah sebagian besar penarinya wanita, sedangkan ciri geraknya adalah sebagian besar gerakan gedrug atau hentakan kaki. Mayoritas penari perempuan tersebut mengakibatkan karakter tari tersebut lebih lembut dan gemulai akan tetapi karakter dasar tari Rampak Buta yang Bringasan masih ada.

Pola tabuhan kendangan yang digunakan tersebut diantaranya pola kendangan sabetan, kicat, dan pola kenangan gedrug atau hentakan kaki atau pola kendangan yang namanya meminjam nama motif gerak tari Jawa. Gerak tari Buta yang lincah tersebut menggambarkan kegembiraan masyarakat yang mengetahui tokoh idamannya (Panji Inukertpati) telah berhasil menemukan kembali Dewi Sekar Taji (Gambar 9).

Adegan tersebut ditutup dengan gerak tari yang menggambarkan kembalinya Dewi Sekartaji ke pangkuan Panji Inukertapati. Peristiwa tersebut dieskpresikan dengan dilemparkan Dewi Sekartari oleh Klono Seandono dan ditangkap oleh Panji Inukertapati (Gambar 10).

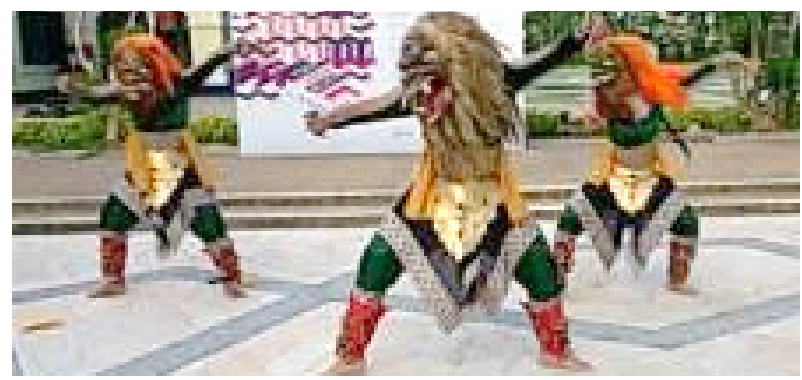

Gambar 9. Pose tubuh adegan penyambutan Panji. (Foto: Raharja, 2018)
Pertunjukan drama tari penembaraan Panji Inukertapati bermisi perdamaian dan tolernasi merupakan sebuah pertunjukan yang menggunakan musik, tari, dan topeng untuk mengisahkan perjalanan Panji Inukertapati mencari Desi Sekar Taji. Bunyi musik dan gerak tari dijadikan simbol untuk menyampaikan kisah pengembaraan Panji Inukertapati mencari Desi Sekar Taji; sedangkan topeng merupakan personifikasi tokoh-tokohnya. Untuk memahami pertunjukan tersebut penonton dituntut memahami simbol-simbol bunyi dan gerak yang ditopang dengan topeng; bunyi musik dan gerak tari merupakan simbol nilai-nilai yang ada dalam suatu daerah, sedangkan topeng merupakan personifikasi tokoh-tokoh dalam cerita tersebut.

Musik iringan pertunjukan drama tari tersebut merupakan sebuah komposisi musik yang dibuat untuk mendukung pertunjukaqn. Caranya membuat nuansa musikal yang disesuaikan dengan suasana adegan; adegan Introduksi, adegan Panji berangkat mengembara, adegan Panji melewati daerah Melayu, adegan Panji melewati wilayah Papua, adegan Panji melewati wilayah Bali, dan adegan Panji ke Jawa. Pada adegan Panji introduksi dibuat nuansa musikal sepi, menyeramkan, dan sejenisnya; sedangkan pada adegan Panji melewati wilayah-wilayah Nusantara salah satu lagu daerahdaerah tersebut dipilih untuk menghadirkan nuansa musikalnya.

Lagu-lagu tersebut, apabila dilihat dari hubungan dengan gerak tarinya, sebagian besar bersifat agak longgar dan longgar. Hubungan sangat ketat terjadi pada adegan penyambutan Panji kembali dari pengembaraan pada kendangan ciblon yang diikuti oleh gerakan sabetan, berjalan, dan sejenisnya. Hubungan agak longgar terjadi pada beberapa adegan, misalnya pada adegan Panji berangkat ketika suasana musikal Jawa dibuat

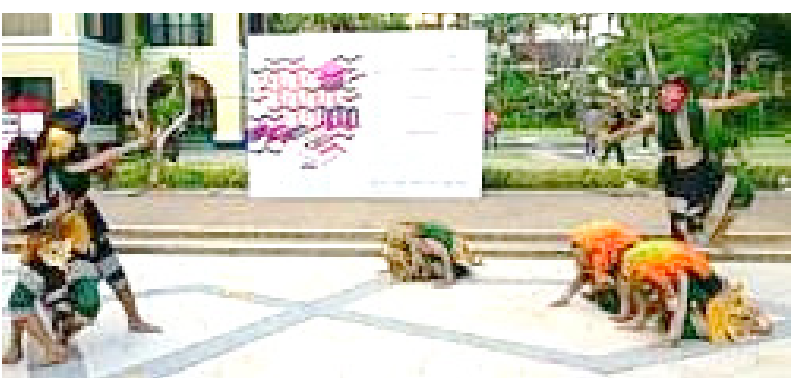

Gambar 10. Pose tubuh adegan kembalinya Dewi Sekartaji. (Foto: Raharja, 2018) 
dengan memainkan gending bedhayan; sedangkan hubungan sangat longgar terjadi pada adegan Panji bertapa, adegan Panji memasuki wilayah Papua.

Penyusunan iringan drama tari pengembaraan Panji ini disusun berdasarkan struktur dinamika pertunjukan. Struktur dinamika pertunjukan berbentuk kerucut tunggal; mulai dari adegan bertapa, berangkat dari Jawa, melewati wilayah Melayu, Papau, Bali, dan kembali lagi ke Jawa. Musik Jawa dihadirkan pada adegan awal dan akhir; karakter gending di awal tempo gendingnya lambat sedangkan pada bagian akhir tempo gendingnya cepat sebagai akibat dari perimbangan penyusunan dinamika pertunjukan tersebut.

Musik-musik tersebut, meskipun digunakan untuk mengiringi gerak tari, akan tetapi tata hubungan antara musik dengan gerak tari tidak selalu mengikuti norma-norma yang ada dalam daerah tersebut. Demikian juga halnya dengan pemaknaannya, musik tersebut digunakan sebagai acuan menentukan gerak tari untuk mengenalkan beragai ragam gerak dalam rangka menayampaikan pesan kekayaan budaya Indonesia.

\section{Penutup}

Berdasarkan uraian tentang iringan pertunjukan di atas dapat ditarik simpulan-simpulan sebagai berikut. Musik iringan drama tari pengembaraan Panji Inukertapati merupakan serangkaian bunyi yang disusun dari bunyi alat musik dan lagu-lagu musik daerah Nusatara. Musik iringan tersebut digunakan untuk menciptakan musikal pertunjukan sebagai penguat ekspresi tari daerah-daerah yang digunakan sebagai penggambaran daerah-daerah yang dilalui perjalanan Panji Inukertapati mengembara di beberapa wilayah Nusantara.

Musik-musik yang digunakan adalah karawitan Jawa atau gending Kinanti Padang Bulan, musik Melayu atau lagu Harum Baunya si Bunga Tanjung, musik Irian Jawa atau lagu Yamko Rambe Yamko, Musik Bali atau gending Gilak, dan gending iringan tari Rampak Buta. Musik iringan tari pertunjukan itu merupakan musik multikultur yang apabila dilihat dari hubungannya dengan gerak tarinya, mempunyai hubungan ketat, agak longgar, dan longgar yang dalam pelaksanaannya tidak mengikuti ketentuan tradisinya akan disesuaikan dengan kebutuhan.

\section{Kepustakaan}

Ambarwangi, S. (2013). Pendidikan Multikultural Di Sekolah Melalui Pendidikan Seni Tradisi. Harmonia - Journal of Arts Research and Education, 13(1).

Asri. (2008). Mengenal Suku Bangsa Di Pegunungan Tengah Papua. Seminar Tema Papua Sudah.

Asri. (2014). Musik Melayu Ghazal Riau Dalam Kajian Estetika. Ekspresi Seni, Jurnal Ilmu Pengetahuan Dan Karya Seni, 16(1), 1-168.

Bahar, M. (2017). Melayu Sebagai Kawasan Budaya

Nusantara Kontinuitas dan Perubahan Budaya

Seni. Jurnal Titian, 1(2), 10.

Desyandri. (2014). Peran Seni Musik dalam Pendidikan Multikultural. Jurnal Pembangunan Pendidikan: Fondasi Dan Aplikasi, Vol 2(1), 1-12.

Donder, I. K. (2005). Esensi Bunyi Gamelan Dalam Prosesi Ritual Hindu: Perspektif Filosofisteologis, Psikologis, Sosiologis dan Sains. Surabaya: Paramita.

Hadi, S. (2017). Kajian Tari, Teks dan Konteks (1st ed.). Yogyakarta: Pustaka Book Publisher.

Herawati, E. N. (2010). Makna Simbolis dalam Tata Rakit Tari Bedhaya. Tardisi, 1(1), 13. Iryanti, V. E. (2000). Tari Bali: Sebuah Telaah Historis. Harmonia: Jurnal Pengetahuan Dan Pemikiran Seni, 1(2), 75-90.

Khojir, K. (2014). Penanaman Nilai-Nilai Multikultural: Studi Kasus Pada Pesantren Nabil Husein Samarinda Kalimantan Timur. Dinamika Ilmu, 14(1), 65-80.

Kleden-probonegoro, N. (2014). Ekspresi Karya

( Seni ) dan Politik Multikultural Sebuah Pengantar. Jurnal Antropologi Indoneisa, 75, $1-5$.

Larasati, C. E. (n.d.). Representasi Identitas Etnis Papua Dalam Film Lost in Papua. Commonline Departemen Komunikasi, 3(3), 488-497.

Malik, F. (2016). Peranan Kebudayaan Dalam Pencitraan Pariwisata Bali. Jurnal Kepariwisataan Indonesia, 11(1), 67-92.

Nalan, A. S. (2017). Pertunjukan Musik Teatrikal 
“IBU ” Produksi Teater Koma. Resital: Jurnal Seni Pertunjukan, 18(1), 13-26.

Neville H. Fletcher. (2007). DIJERIDO.pdf. Journal of ITC Sangeet Academy, 21, 15.

Nurcahyono, O. H. (2018). Pendidikan

Multikultural Di Indonesia: Analisis Sinkronis Dan Diakronis. Habitus: Jurnal Pendidikan, Sosiologi Dan Antropologi, 2(1), 105-115. Retrieved from

Rahayu, R. (2018). Karawitan Tari Topeng Sekartaji Tunggal. Keteg, Jurnal Pengetahuan, Pemikirna, Dan Kajian Tentang Bunyi, 18(2). Regina. (2014). Cerita Panji dalam Tradisi Lisan Masyarakat Kalimantan. In Prosiding Tokoh Panji Nasional Indonesia "Panji dalam Berbagai Tradisional Nusantara (p. 7).

Rina Martiara. (2018). Malay Dance: Expression on Maritime Society. Dance and Theatre Revoew, Jurnal Tari, Teater, Dan Wayang, 1(1), 50-58.

Ruastiti, N. M., Parmi, N. W., Nyoman, N., Suryani, M., \& Sudiana, I. N. (2018). Davedan Show Di Amphi Theatre Nusa Dua Bali. Mudra, Jurnal Seni Dan Budaya, 33(April), 278-286.

Rumansara, E. (2014). Memahami Kebudayaan Lokal Papua: Suatu Pendekatan Pembangunan Yang Manusiawi. Jurnal Ekologi Birokrasi, 1(1), 47-57. Retrieved from

Rustiyanti, S. (2015). Musik Internal dan Eksternal dalam Kesenian Randai. Resital: Jurnal Seni Pertunjukan, 15(2), 152-162. https://doi. org/10.24821/resital.v15i2.849

Santosa. (2011). Komunikasi Seni. Surakarta: ISI Press Surakarta.

Sheperd, John dan Wicke, P. (1997). Music and
Cultural Theory (1st ed.). Malden: Blackwell Production Ltd.

Subuh, \& Prasetyo, Y. (2009). Iringan Kuda Lumping Ngesti Budaya. Resital, 10(1), 12.

Sugiartha, I. G. A. (2018). Relation of Dance and Music to Balinese Hinduism. Spafa Journal, 1(1), 1-27.

Sukerta, P. M. (2011). Metode Penyusunan Karya Musik (Sebuah Alternatif). Surakarta: ISI Press Surakarta.

Sumaryono. (2004). Seni Karawitan Sebagai Iringan Tari, Studi Analisis Tata Hubungan (Laporan Penelitian). Yogyakarta: Lembaga Penelitian ISI Yogyakarta.

Supardi. (2013). Ricikan Struktural Salah Satu Indikator Pada Pembentukan Dalam Karawitan Jawa. Keteg, Jurnal Pengetahuan, Pemikirna, Dan Kajian Tentang Bunyi, 13(1), 2-28.

Supriatna, Atang dan Sastra Negara, R. (2010). Pendidikan Seni Tari untuk SMP/MTs. Jakarta: Pusat Perbukuan Kementerian Pendidikan Nasional.

Suyoto, \& Haryono, T. (2015). Vokal dalam Karawitan Jawa Gaya Surakarta. Keteg, Jurnal Pengetahuan, Pemikirna, Dan Kajian Tentang Bunyi, 15(1).

Wijayanti, D., \& Indriyanti, P. (2017). Pendidikan Multikultural Berbasis Seni Budaya Di Sd Taman Muda Ibu Pawiyatan Yogyakarta. SOSIOHUMANIORA: Jurnal Ilmiah Ilmu Sosial Dan Humaniora, 2(1).

Zulyani Hidayah. (2015). Ensiklopedi Suku Bangsa di Indoensia. Jakarta: Yayasan Pustaka Obor Indonesia. 